Cyclosporin A (CsA) is an im munosuppresor drug that $h$ as been used in the treatment of several types of inflammatory diseases. In some of them the inhibition of T-lymphocyte activation does not suitably account for the observed beneficial effect, suggesting that CsA could act on other types of cells. The present study was undertaken to determine the effect of CsA on inflammatory cytokine secretion by U937 monocyte cells. Undifferentiated and dimethylsulfoxide (DMSO) differen tiated U937 cells were incubated with different concentrations of CsA $(200,20$ and $2 \mathrm{ng} / \mathrm{mL})$ in the presence or absence of phorbol-myristateacetate (PMA). In terleukin-1 $\beta$ (IL-1 $\beta$ ), tumor necros is factor- $\alpha$ (TNF- $\alpha)$, IL-6 and IL-8 levels were measured in supernatants using specific enzyme-linked immunosorbent assays. At the highest concentration used $(200 \mathrm{ng} / \mathrm{mL})$ CsA decreased the basal and stimulated secretion of all the inflam matory cytokines studied in both undifferentiated and differentiated cells, with the only exception of PMA-stimulated IL-1 secretion by undifferentiated cells. However, only basal secretion of interleukin-8 in both undifferentiated and DMSO-differentiated U937 cells was significantly reduced by $\mathrm{Cs} \mathrm{A}$ at the highest concentration (200 ng/ $\mathrm{mL}$ ). At therapeutic concentrations in vivo, CsA exerts a predominant effect on IL-8 secretion by human mononuclear phagocytes.

Key words: Cyclosporin, Cytokine, U937, Macrophage, Monocyte

\section{Effect of cyclosporin A on inflammatory cytokine production by U937 monocyte-like cells}

\author{
Juan E. Losa Garcia, ${ }^{\text {CA, a }}$ \\ María Rosa Martín de Cabo, ${ }^{b}$ \\ Fernando Mateos Rodríguez, c Jesús Pérez Losada, ${ }^{d}$ \\ Antonio Jiménez López ${ }^{\mathrm{d}}$ and \\ José Luis Pérez Arellano
}

${ }^{a}$ Fundación Hospital de Alcorcón, dUniversidad de Salamanca, ${ }^{b}$ Centro de Salud Miguel Servet, Alcorcón, 'Hospital General de Albacete, e Departamento de Ciencias Clínicas, Universidad de Las Palmas, Las Palmas, Spain
${ }^{\mathrm{CA}}$ Corresponding Author
Tel: +34916219513
Fax: +34916219901
E-mail: jelosa@fhalcorcon.es

\section{Introduction}

Cyclosporin A (CsA) is an immunomodulatory substance used in the prevention of transplant rejection and in the treatment of autoimmune diseases. ${ }^{1}$ Classically, CsA has been reported to exert its immunomodulatory action through its effect on $\mathrm{T}$ lymphocytes, mainly helperT lymphocytes, by inhibiting calcineurin dependent interleukin (IL)-2 synthesis. $^{2,3}$ However, it has been suggested that the inhibition of T lymphocyte activation by CsA does not appropriately account for all the effects observed following the in vivo administration of the drug. ${ }^{4}$ It is possible that some effects could be due to the action of CsA on other cells. ${ }^{5}$ It should be noted that CsA binds to all human leucocytes. In fact, granulocytes and cells of the mononuclear phagocyte system (MPS) sometimes bind more CsA than lymphocytes, probably because the drug is rapidly internalized. ${ }^{2,6}$

Cells of the MPS offer an attractive possibility to study the effects of this drug because they participate in a crucial manner in antigen presentation and, in many cases, are the final effectors of the immune system. Many references in the literature report the capacity of CsA to alter the activities of MPS cells. In general, the capacities, functions and actions of macrophages related to non-specific defense such as chemotaxis, phagocytosis, enzyme release and respiratory burst, are found to be more resistant to $\mathrm{CsA} .^{7,8}$ By contrast, those related to immunoregulation or accessory functions, such as monokine production, the expression of histocompatibility antigens and antigen presentation, are more susceptible to the inhibitory action of CsA. ${ }^{7,8}$

Macrophages synthesize and secrete IL-1 $\beta$, tumor necrosis factor (TNF)- $\alpha$, IL- 6 and IL-8. ${ }^{9}$ These monokines are known mediators of the inflammatory response ${ }^{9}$ and are therefore also known as inflammatory cytokines.

The aim of the present study was to evaluate the effect of CsA on the secretion of IL-1 $\beta$, TNF- $\alpha$, IL- 6 and IL-8 by U937 monocyte-like cells.

\section{Material and methods}

\section{Cell line}

U937 cells were kindly supplied by Dr J. Olmos from the Hospital Universitario Marqués de Valdecilla, Santander (Spain). The cell line was kept at $37^{\circ} \mathrm{C}$ in a 
humidified atmosphere with $5 \% \mathrm{CO}_{2}$ in culture with complete medium containing RPMI 1640 (Sigma ${ }^{\circledR}$ ), $100 \mathrm{U} / \mathrm{mL}$ of penicillin (Sigma ${ }^{\circledR}$ ), $100 \mathrm{U} / \mathrm{mL}$ of streptomycine (Sigma $\left.{ }^{\circledR}\right), 2 \mathrm{mM}$ L-glutamine (Sigma ${ }^{\circledR}$ ) and $10 \%$ fetal calf serum (FCS) (Gibco ${ }^{\circledR}$ ) in sterile culture flasks (Nunclon ${ }^{\circledR}$ ) at a concentration between $0.75 \times 10^{5}$ and $5 \times 10^{5}$ cells $/ \mathrm{mL}$. Cell viability was greater than $90 \%$ and the duplication time was between 24 and 48 hours. Cells were regularly screened for lipopolysaccharide (LPS), bacteria, mycoplasma and fungal contamination and found to be negative. Cells were differentiated by incubation over 4 days in complete medium containing $1.3 \%$ (0.17 M) dimethylsulfoxide (DMSO).

\section{Cell cultures}

$5 \times 10^{5}$ cells together with different stimuli and/or CsA at different concentrations were added to each well of the culture dishes (Costar ${ }^{\circledR}$ 3513, 12 dishes $22.6 \mathrm{~mm}$ $\varnothing)$ with complete medium: Lipopolysaccharide from E. coli (Sigma ${ }^{\circledR}$ ) at $100 \mu \mathrm{g} / \mathrm{mL}, 10 \mu \mathrm{g} / \mathrm{mL}$ and $1 \mu \mathrm{g} / \mathrm{mL}$; phorbol-12-myristate-13-acetate (PMA) (Sigma ${ }^{\circledR}$ ) at $10^{-4} \mathrm{M}, 10^{-5} \mathrm{M}$ and $10^{-6} \mathrm{M}$; human gamma-interferon $\left(\right.$ Sigma $\left.{ }^{\circledR}\right)$ at 1000,100 and $10 \mathrm{U} / \mathrm{mL}$ and CsA (Sandoz $\AA$ ) at three non-toxic in vivo concentrations: 200,20 and $2 \mathrm{ng} / \mathrm{mL}$.

Cells were kept at $37^{\circ} \mathrm{C}$ in a humidified atmosphere with $5 \% \mathrm{CO}_{2}$ for $18 \mathrm{~h}$, after which supernatants were centrifuged at $500 \mathrm{~g}$ for $10 \mathrm{~min}$ to sediment cells in suspension and then stored at $-70^{\circ} \mathrm{C}$ until assayed.

\section{Cytokine determination}

The inflammatory cytokines were determined by direct double-sandwich enzyme-linked immunosorbent assay (ELISA) in the supernatants. BIOTRAK ${ }^{\circledR}$ (Amersham, UK) commercial kits specific for human IL-1 $\beta$, TNF- $\alpha$, IL- 6 and IL- 8 were used; these showed no cross-reactivity with one another, or with other cytokines. They had a coefficient of variation less than $10 \%$, and the following respective sensitivity limits: $0.3 \mathrm{pg} / \mathrm{mL}, 4.8 \mathrm{pg} / \mathrm{mL}, 0.35 \mathrm{pg} / \mathrm{mL}$ and $4.7 \mathrm{pg} / \mathrm{mL}$. All samples were measured in duplicate. Results were expressed in picograms $/ 10^{6}$ cells. None of the components of the culture medium (RPMI 1640, antibiotics, glutamine or fetal calf serum) showed immunoreactivity with the four types of cytokines studied.

\section{Statistical analysis}

All data are expressed as means \pm SEM. For each cytokine $t$-test for paired data was used to compare the differences in cytokine secretion between CsA treated and untreated cells; $p$ values $<0.05$ were considered significant.

\section{Results}

\section{Differentiation of the U937 line}

The data (not shown) confirming that suitable differentiation of the monocyte cell line toward macrophage cells had been achieved were as follows:

- A decrease in the cellular proliferation rate without changing cell viability.

- An increase in adherence to the culture flasks and among cells.

- An increased cytoplasm, the disappearance of nuclear polylobulation and a decrease in nuclear atypias and the number of nucleoli.

- An increase in the content of macrophage enzymes (non-specific esterases).

- An increase in cytoplasmic RNA content.

\section{Determination of type of stimulus and most effective concentration on inflammatory cytokine secretion}

In order to study the most suitable type of stimulus for inducing the secretion of inflammatory cytokines and the most effective concentration, U937 cells were used under both differentiated and undifferentiated conditions. Three classic stimuli were studied at three different concentrations: lipopolysaccharide (LPS), phorbol myristate acetate (PMA) and gamma-interferon $(\gamma$-IFN). The mean values of the results of the study carried out in duplicate are shown for each cytokine in Fig. 1. Overall, the data obtained indicate that the most potent stimulus of cytokine secretion was PMA at a concentration of $10^{-5} \mathrm{M}$.

\section{Secretion of inflammatory cytokines by U937 cells}

Once the required experimental conditions had been established, inflammatory cytokine secretion by U937 cells was studied (Table 1). In basal conditions U937 cells secrete large amounts of IL-8, moderate amounts of IL- 6 and TNF- $\alpha$ and low amounts of IL- $1 \beta$. The stimulation with PMA induces a large increase in the secretion of all cytokines. Only IL-6 secretion was stronger in differentiated than in undifferentiated cells.

\section{Effect of CsA on inflammatory cytokine secretion}

The results on the effect of CsA on cytokine secretion under both basal and stimulated conditions are shown in Table 1 . These data show the mean values obtained in four different assays. At therapeutic in vivo concentrations $(200 \mu \mathrm{g} / \mathrm{mL})$ CsA decreased basal and stimulated secretion of all the inflammatory cytokines studied in both undifferentiated and differentiated 


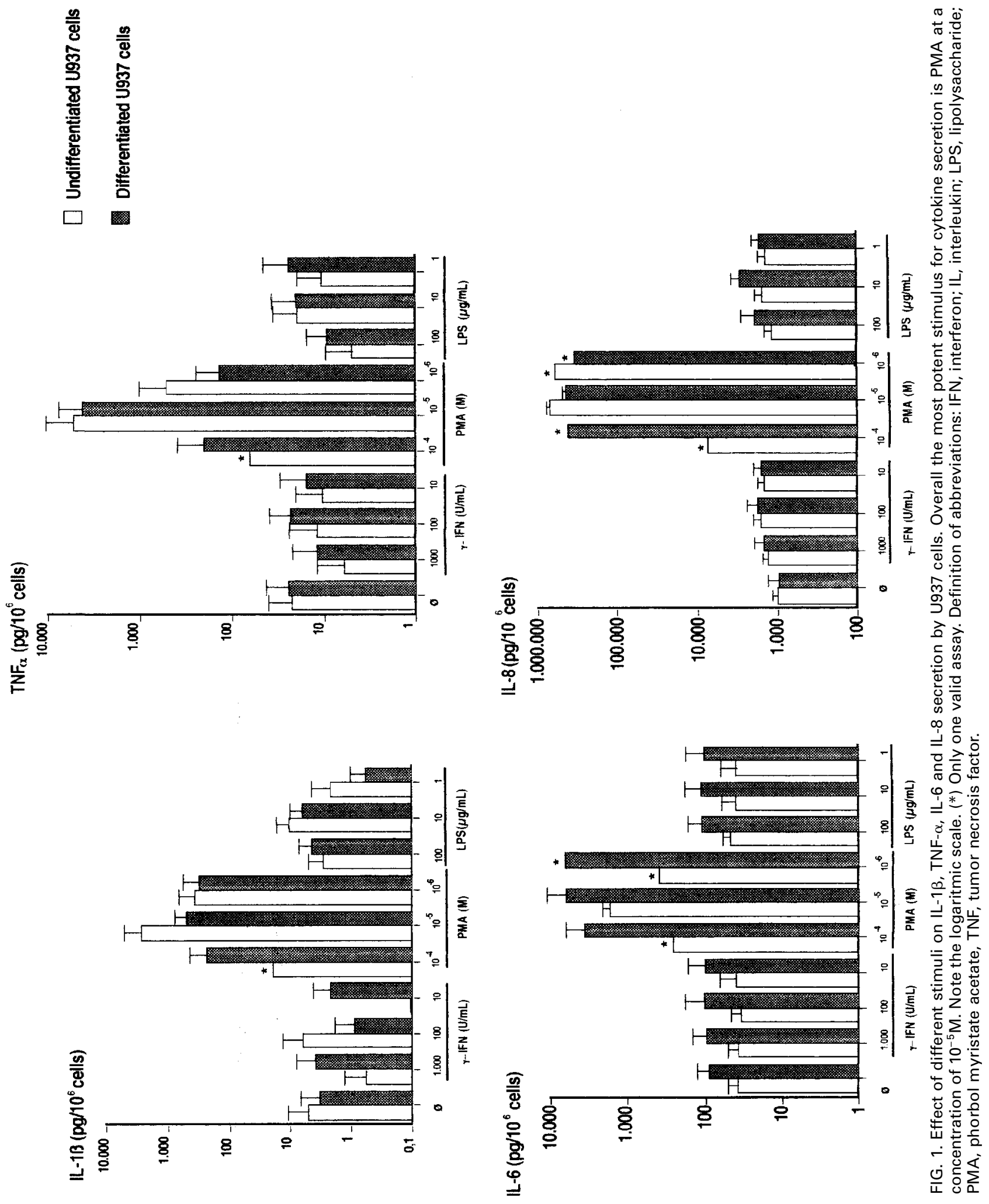


Table 1. Effect of CsA on basal and stimulated IL-1 $\beta$, TNF- $\alpha$, IL- 6 and IL- 8 secretion by U937 cells (pg/ $10^{6}$ cells). The CsA reduction of inflammatory cytokine secretion has stadistical significance only in the case of basal IL-8 secretion in both undifferentiated and differentiated cells. Data are expressed as mean \pm SEM

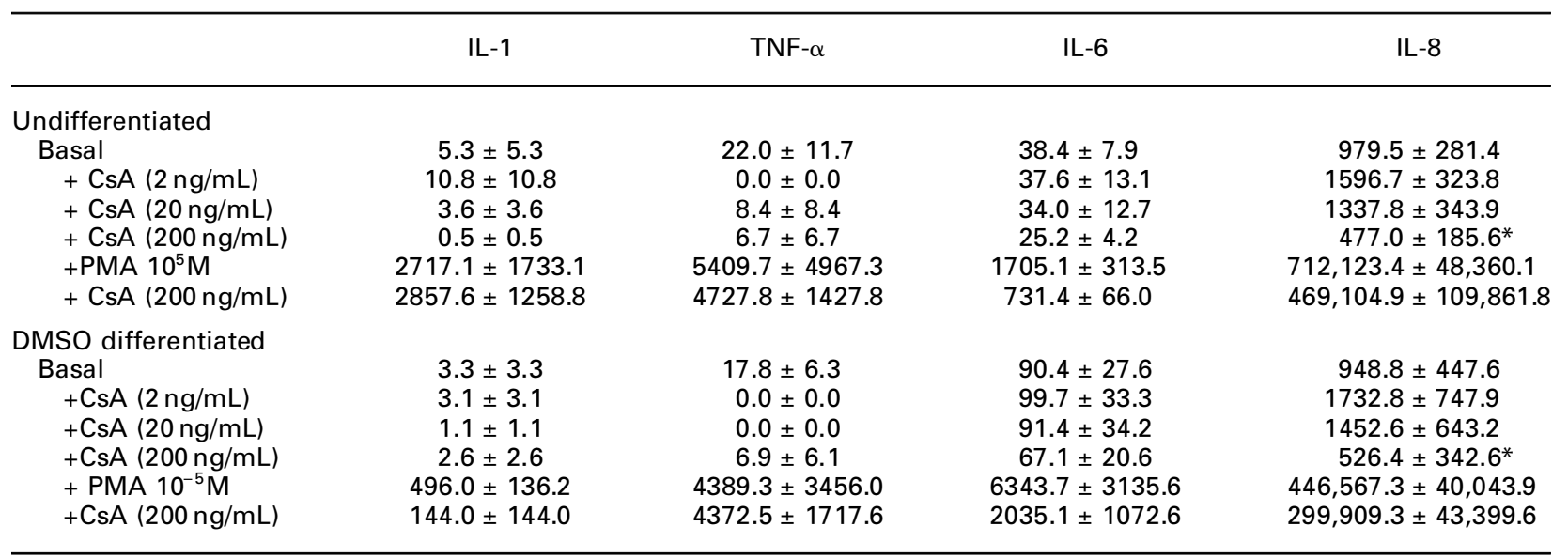

* $p<0.05$ determined by $t$-test for paired data to compare cytokine secretion between $\mathrm{CsA}$ treated and untreated cells. Definition of abbreviations: CsA, cyclosporin A; DMSO, dimethylsulfoxide; IL interleukin; PMA, phorbol myristate acetate; TNF- $\alpha$, tumor necrosis factor alpha.

cells, with the only exception being PMA-stimulated IL-1 secretion by undifferentiated cells. However, only basal secretion of interleukin-8 in both undifferentiated and DMSO-differentiated U937 cells was significantly reduced by CsA at the highest concentration used $(200 \mathrm{ng} / \mathrm{mL})$.

\section{Effect of CsA on cell viability and cell proliferation capacity}

The inhibitory effect of CsA might be due to an effect on cell viability and/or proliferation. Subsequently, a duplicate study was performed in which the proliferation capacity and cell viability of U937 cells subjected to the same stimuli as to those used in the study were evaluated. As shown in Table 2, CsA did not affect either viability or proliferation capacity, either in undifferentiated U937 cells or in cells differentiated with DMSO. Therefore the results on cytokine secretion cannot be interpreted in these terms. In this study, the effects of several stimulatory substances were also assessed. Both PMA and LPS, but not gamma-interferon, were shown to decrease cell viability.

\section{Discussion}

The use of the U937 cell line in the evaluation of different macrophage functions is well documented. ${ }^{10}$ This human cell line grows continuously in suspension and was initially obtained from a pleural effusion in a patient with histiocytic lymphoma. ${ }^{11}$ Its phenotype corresponds to immature monocyte cells arrested in a differentiation state close to the myelomonocytic stem cell. ${ }^{11}$ It should be recalled that macrophages are highly differentiated cells and therefore have low proliferation capacity while cell lines show a strong duplication rate. Thus, the first step in our work was to differentiate the human U937 monocyte cell line. In the presence of several substances U937 cells undergo a process of differentiation and therefore acquire morphological and

Table 2. Effect of CsA and of different stimuli on cell proliferation and viability. In this study we started out with a viable cell concentration of $250,000 \mathrm{~mL}$, obtaining the data after $18 \mathrm{~h}$ of culture. CsA did not affect either the viability or proliferation capacity of either differentiated or undifferentiated cells. Additionally, both LPS and PMA, but not interferon, decreased cell viability

\begin{tabular}{|c|c|c|c|c|}
\hline & \multicolumn{2}{|c|}{ Undifferentiated U937 cell line } & \multicolumn{2}{|c|}{ Differentiated U937 cell line } \\
\hline & Viable cells $/ \mathrm{mL}$ & Viability (\%) & Viable cells/mL & Viability (\%) \\
\hline Basal conditions & 370,000 & 91 & 317,000 & 95 \\
\hline PMA $10^{-5} \mathrm{M}$ & 240,000 & 84 & 128,000 & 76 \\
\hline LPS $(100 \mu \mathrm{g} / \mathrm{mL})$ & 335,000 & 88 & 280,000 & 88 \\
\hline$\gamma$-interferon $(1000 \mathrm{U} / \mathrm{mL})$ & 400,000 & 94 & 285,000 & 92 \\
\hline CsA (200 ng/mL) & 385,000 & 94 & 300,000 & 93 \\
\hline $\mathrm{CsA}(200 \mathrm{ng} / \mathrm{mL})+\mathrm{PMA} 10^{-5} \mathrm{M}$ & 240,000 & 77 & 115,000 & 81 \\
\hline
\end{tabular}

Definition of abbreviations: CsA, cyclosporin A; LPS, lipopolysaccharide; PMA, phorbol myristate acetate. 
functional characteristics similar to those of macrophages. ${ }^{12}$ Since one of the interests of the present work was to assess the effect of PMA on cytokine secretion, DMSO was chosen as a differentiating agent because it displays differentiating capacity on the $\mathrm{U} 937$ cell line. ${ }^{13}$ Differentiation was evaluated by kinetic, morphological, cytochemical and molecular techniques. The results obtained, which were similar to those reported by other authors, ${ }^{11,13}$ allowed us to conclude that the protocol used is indeed able to promote the differentiation of this cell line.

DMSO-differentiated U937 cells retain their capacity to be stimulated later on with different agents, ${ }^{13}$ among them PMA. ${ }^{14}$ It should be noted here that differentiation and activation are not incompatible concepts and that it is in fact possible to employ several substances ${ }^{12}$ to activate cells differentiated with other agents. Here, we evaluated the effect of three known macrophage stimulating agents and observed that for this purpose the most suitable agent was PMA at a concentration of $10^{-5} \mathrm{M}$. Although according to the literature lower concentrations of this substance are usually used, ${ }^{11,13}$ in each experimental system it is necessary to obtain evidence of the most effective concentration in the induction of a given effect. In the present study the above concentration was used. Although at this concentration PMA directly decreases cellular viability, from a quantitative point of view the increase that it induces in cytokine secretion cannot be attributed to the elimination of cytokines by dead cells.

The cytokine secretion pattern observed under both basal and PMA-stimulated conditions in this cell line was similar to that of tissue macrophages such as human alveolar macrophages. ${ }^{9,15}$ Different studies have documented the production of inflammatory cytokines by U937 cells using bioassays, ${ }^{16}$ immunoassays $^{17-20}$ or molecular biology techniques, ${ }^{16,19}$ although none of them used a protocol identical to the one used here. From the quantitative point of view, the results obtained here are similar to those reported by Hass et a $l$. regarding IL1, TNF and IL- $6^{17}$ and by Bosco et al. ${ }^{19}$ regarding IL-8, although the former authors ${ }^{17}$ did not detect IL-6 secretion, possibly due to the stimulation conditions. By contrast, the values described by Jiang et a . $^{18}$ for IL-1, TNF and IL-6 and by Nishimura $e t a l .^{21}$ for TNF are lower than our own, although both authors also used different protocols. A different protocol was also used by Srivastava et al., ${ }^{20}$ who reported much higher amounts of spontaneously secreted IL-8 in comparison with the present values. However, none of these works evaluated the release of the four cytokines studied here jointly.

Only basal secretion of interleukin-8 in both undifferentiated and DMSO-differentiated U937 cells was significantly reduced by CsA at the highest concentra- tion used $(200 \mathrm{ng} / \mathrm{mL})$. Our group has previously demonstrated that CsA decreases IL-8 secretion in human alveolar macrophages, ${ }^{22}$ however Mrowietz et al. have found that human monocyte interleukin-8 secretion is not inhibited by $\mathrm{CsA}^{23}$ but they only studied stimulated secretion and used higher and in vivo toxic concentrations of CsA. The effect of CsA on the U937 cell line is not well documented; in fact, only two works have evaluated the action of this immunomodulator on cytokine secretion. ${ }^{10,24}$ In this sense, Tadmori et a.$^{24}$ have shown that CsA decreases TNF- $\alpha$ secretion in U937 cells, although these authors used extremely high concentrations, and Keicho et $a l{ }^{10}$ report the inhibitory effect of this immunomodulator on IL- $1 \alpha$ secretion. In these two works incubations were higher than $24 \mathrm{~h} .^{10,24}$

The CsA reduction of IL-8 secretion by human macrophages is an interesting finding that may help to explain the efficacy of CsA treatment in diseases like psoriasis or pulmonary fibrosis in which neutrophilic infiltration is a key pathogenetic event..$^{7,25,26}$ It has been demonstrated that CsA inhibits lymphocyte chemotaxis $^{27}$ and pulmonary recruitment of inflammatory leukocytes ${ }^{5}$ and that interleukin-8-a chemokine that recruits and activates neutrophils - is a cyclosporin A binding protein. ${ }^{28}$ Furthermore the cyclosporin binding proteins or cyclophilins are chemotactic for eosinophils and neutrophils ${ }^{29}$ and their chemotactic activity is inhibited by CsA. ${ }^{29}$ Therefore it seems that CsA modulates chemotaxis. ${ }^{29}$ In the opinion of some authors, blocking of chemotaxis may be the principal reason for the therapeutic effect of cyclosporin in patients with diseases like psoriasis. $^{30}$

\section{References}

1. Fathman CG, Myers BD. Cyclosporine therapy for autoimmune disease. $N$ Engl J Med 1992: 326:1693-5.

2. Hess AD, Colombani PM, Esa AH. Cyclosporine and the immune response: basic aspects. Crit Rev Im munol 1986: 6:123-49.

3. Schreiber SL, Crabtree GR. The mechanisnm of action of cyclosporin A and FK506. Imm unol Today 1992: 13:136-42.

4. Ren K, Van Liew JB, Noble B. The effect of cyclosporin A on disease progression in proliferative immune complex glomerulonephritis. Clin Im munol Im munopathol 1993; 66: 107-13.

5. Chapman I, Mazzoni L. Mechanisms of inhibition by cyclosporin A on pulmonary leukocyte accumulation. Trends Pharmacol Sci 1994; 15:99-101.

6. Ryffel B, Willard-Gallo KE, Tammi K, Loken MR. Quantitative fluorescence analysis of cyclosporine binding to human leukocytes. Transplantation 1984; 37:276-80.

7. Mrowietz U, Christophers E. Effects of cyclosporine A treatment on psoriasis. I: influence of low-dose cyclosporine on human monocyte function in vitro. Transplant Proc 1988; 20(Suppl 4):53-7.

8. Losa JE, Mateos F, Jiménez A, Pérez JL. Action of cyclosporin A on mononuclear phagocytes. J Invest Allergol Clin Immunol 1996: 6:222-31.

9. Losa JE, Mateos F, Mart'n MR, et al. Evaluation of inflammatory cytokine secretion by human alveolar macrophages. Mediat Inflamm 1999; 8:43-51

10. Keicho N, Sawada S, Kitamura K, Yotsumoto H, Takaku F. Effects of an immuno-suppressant, FK506, on interleukin 1 alpha production by human macrophages and a macrophage-like cell line, U937. Cell Imm unol 1991; 132: 285-94.

11. Minta JO, Pambrun L. In vitro induction of cytologic and functional differentiation of the immature human monocytelike cell line U-937 with phorbol myristate acetate. Am J Pathol 1985; 119: 111-26. 
12. Öberg F, Botling J, Nilsson K. Macrophages and the cytokine network Transplant Proc 1993; 25: 2044-7.

13. SakanoT, Fujie A, HamasakiT, Harada Y, Taniguchi H, Ueda K. Intracellular $\mathrm{Ca}^{2+}$ mobilization in immature and more mature U937 induced to differentiate by dimethyl sulfoxide or phorbol myristate acetate. Cell Im munol 1988: 111: 390-7.

14. Rzigalinski BA, Rosenthal MD. Effects of DMSO-induced differentiation on arachidonate mobilization in the human histiocytic lymphoma cell line U937: responsiveness to sub-micromolar calcium ionophore A23187 and phorbol esters. Biochem Biophys Acta 1994; 1223:219-25.

15. Thomassen MJ, Meeker DP, Antal JM, Connors MJ, Wiedemann HP Synthetic surfactant (Exosurf) inhibits endotoxin-stimulated cytokine secretion by human alveolar macrophages. Am J Respir Cell Mol Biol 1992; 7: 257-60.

16. Taimi M, Defacque H, Commes T, et a l. Effect of retinoic acid and vitamin $\mathrm{D}$ on the expression of interleukin-1 beta, tumour necrosis factor-alpha and interleukin-6 in the human monocytic cell line U937. Im mu nology 1993; 79: 229-35.

17. Hass R, Lonnemann G, Mannel D, et a l. Regulation of TNF-alpha, IL-1 and IL-6 synthesis in differentiating human monoblastoid leukemic U937 cells. Leuk Res 1991; 15: 327-39.

18. Jiang WG, Puntis MC, Hallett MB. U937 cells stimulated with opsonised zymozan particles provide a convenient laboratory source of tumour necrosis factor alpha. J Im mu nol Methods 1992; 152: 201-7.

19. Bosco MC, Gusella GL, Espinoza-Delgado I, Longo DL, Varesio L. Interferon-gamma upregulates interleukin-8 gene expression in human monocytic cells by a posttranscriptional mechanism. Blood 1994; 83 537-42

20. Srivastava MD, Srivastava R, Srivastava BI. Constitutive production of interleukin-8 (IL-8) by normal and malignant human B-cells and other cell types. Leuk Res 1993; 17: 1063-9.

21. Nishimura K, Hashimoto Y, Iwasaki S. Enhancement of phorbol esterinduced production of tumor necrosis factor alpha by thalidomide. Biochem Biophys Res Commun 1994; 199: 455-60.
22. Losa JE, Mateos F, Jiménez A, et al. Effect of cyclosporin A on inflammatory cytokine production by human alveolar macrophages. Respir Med 1998; 92: 722-8.

23. Mrowietz U, Sticherling M, Mielke V, Schröder JM, Christophers E Neutrophil-activating peptide 1 /interleukin 8 mRNA expression and protein secretion by human monocytes: effect of cyclosporin A. Cytokine 1991; 3: 322-6.

24. Tadmori W, Mondal D, Tadmori I, Prakash O. Transactivation of human immunodeficiency virus type 1 long terminal repeats by cell surface tumor necrosis factor alpha. J Virol 1991; 65: 6425-9.

25. Wong RL, Winslow CM, Cooper KD. The mechanisms of action of cyclosporin A in the treatment of psoriasis. Im munol Today 1993; 69-74.

26. Losa JE, Mateos F, Jiménez A, Pérez JL. Ciclosporinay enfermedad pulmonar alveolointersticial difusa. Arch Bronconeumol 1996; 32 302-6.

27. Adams DH, Wang LF, Neuberger JM, Elias E. Inhibition of leukocyte chemotaxis by immunosuppressive agents. Specific inhibition of lymphocyte chemotaxis by cyclosporine. Transplantation 1990; 50: 845-50.

28. Bang H, Brune K, Nager C, Feige U. Interleukin-8 is a cyclosporin A binding protein. Experientia 1993; 49: 533-8.

29. Xu Q, Leiva MC, Fisch off MK, Handschumacher RE, Lyttle CR. Leukocyte chemotactic activity of cyclophilin. J Biol Che m 1992; 267: 11968-71.

30. Erlanger BF. Why cyclosporin is an effective drug. Im m u nol To day 1993 14: 369

\section{Received 2 May 2000;}

accepted after revision 21 August 2000 


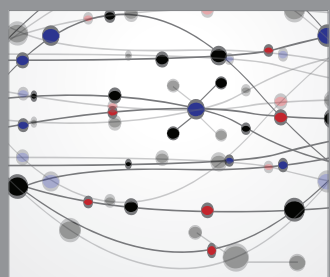

The Scientific World Journal
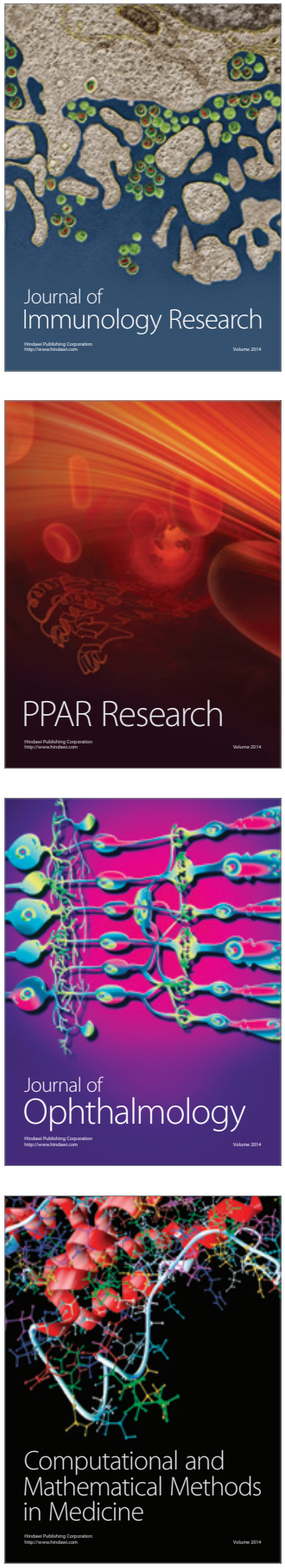

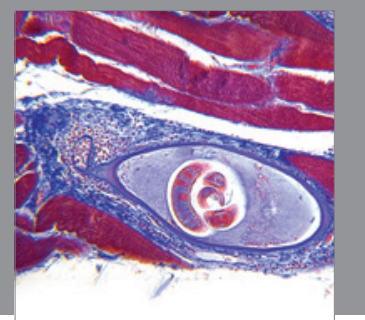

Gastroenterology

Research and Practice
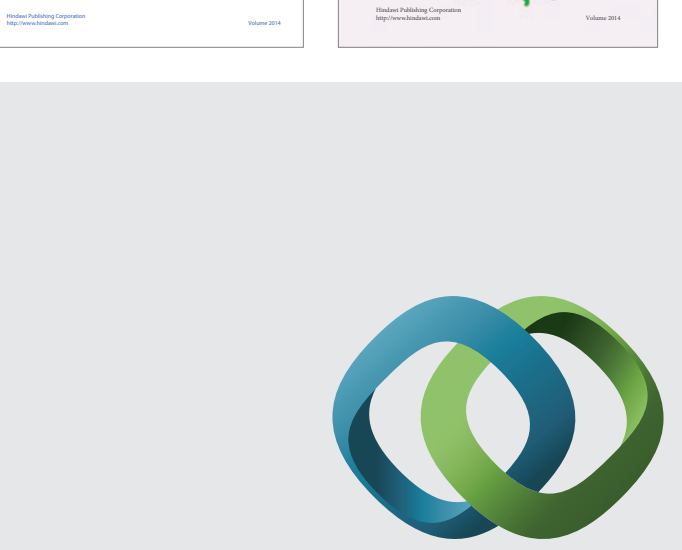

\section{Hindawi}

Submit your manuscripts at

http://www.hindawi.com
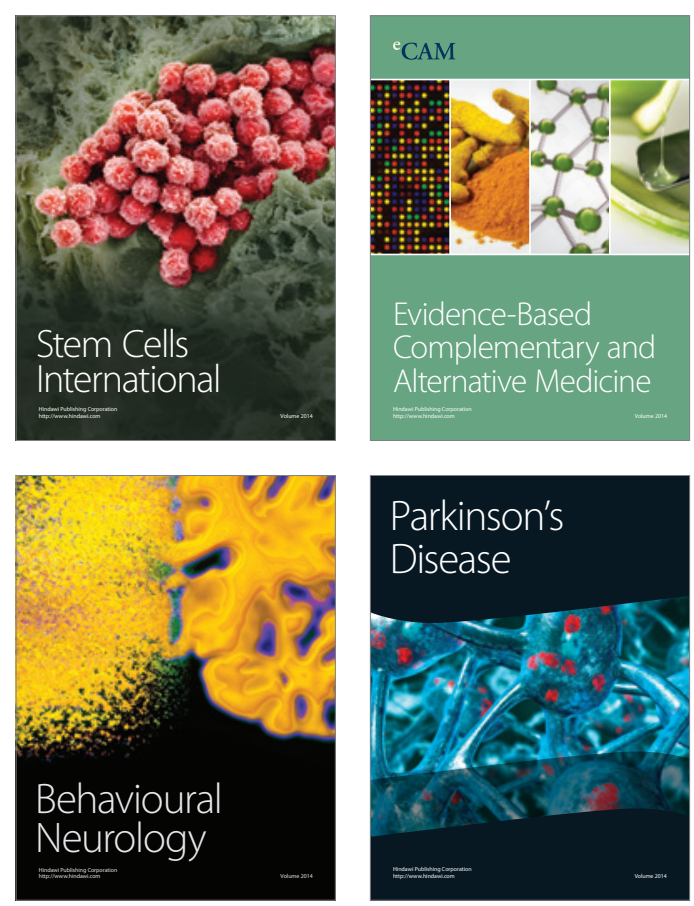

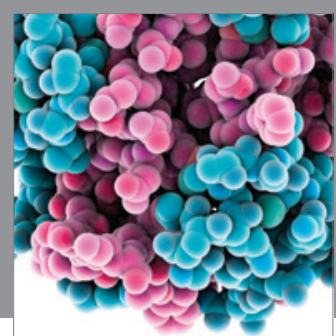

Journal of
Diabetes Research

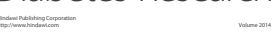

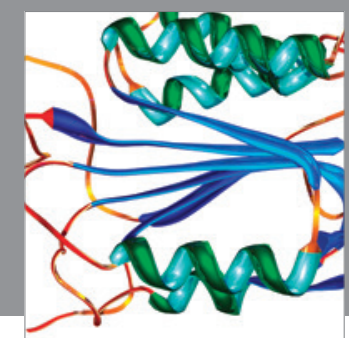

Disease Markers
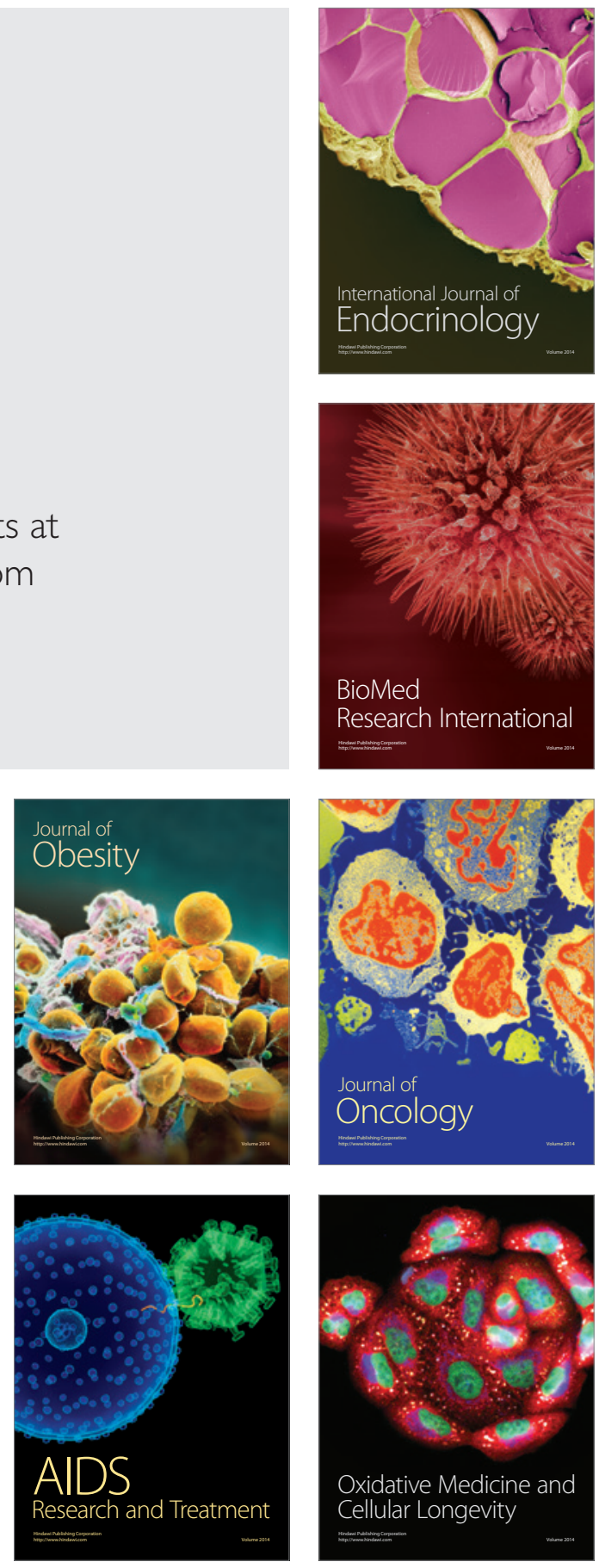